\title{
RASGRF2 Gene
}

National Cancer Institute

\section{Source}

National Cancer Institute. RASGRF2 Gene. NCI Thesaurus. Code C39939.

This gene plays a role in signal transduction and receptor signaling. 